\title{
多孔質ガラスにおける含浸成分の分布と コロイド状シリカの不均一性
}

\author{
田中博史・矢沢哲夫 ·若林 肇 - 中道弘 - 江口清久
}

（大阪工業技術試験所）

\section{Distribution of Impregnated Component and Nonuniformity of Colloidal Silica in Porous Glass}

\author{
Hiroshi TANAKA, Tetsuo YAZAWA, Hajimu WAKABAYASHI, Hiroshi NAKAMICHI and Kiyohisa EGUCHI \\ $\left(\begin{array}{ll}\text { Government Industrial Research Institute, } & \text { Osaka } \\ \text { 8-31, Midorigaoka 1-chome, Ikeda-shi } & 563\end{array}\right)$
}

Porous glass prepared by acid leaching of phase separated glass contains colloidal silica, resulting in the nonuniformity in the porous glass. Porous glass rods were impregnated with aluminum nitrate solutions, and some of them were treated subsequently with ammonia to precipitate aluminum hydroxide. Then the porous glasses were sintered to form nonporous glasses. The concentration profile of aluminum in the sintered glasses was studied with reference to the nonuniformity. The aluminum concentration in the impregnated and ammonia-treated specimens was high at the surface region and decreased toward the center. This fact coincides with the distribution of porosity which is high at the surface region. The concentration difference between the as-impregnated and impregnated and ammonia-treated specimens was large at the center and decreased toward the surface, in good correlation with the distribution of the surface area which is high at the center. A narrow gap with a low aluminum concentration was observed at the center of the impregnated specimen and was ascribed to the very densely deposited colloidal silica.

[Received May 21, 1986]

Key-words : Porous galss, Colloidal silica, Nonuniformity, Porosity, Surface area, Impregnation

\section{1. 緒 言}

ナトリウムホウケイ酸ガラスを熱処理して分相させ, 可溶性のホウ酸塩相を酸で溶出することによって高ケイ 酸多孔質ガラスが作られる1).このとき, ホウ酸塩相に 含まれていたシリカがコロイド状になって多孔構造中に 析出する ${ }^{1) \sim 5)}$. このコロイド状シリカは多孔質ガラスの 表面特性に著しい影響を与えるが，多孔質ガラス内にお ける分布が一様でないため, 多孔質ガラスに不均一性を もたらす。このような不均一性としては，コロイドの析 出量が試料表面から中心に向かって増加すること ${ }^{4), 6)} に$ よるもの, 酸処理中にコロイド状シリカ粒子が成長する ことヤによるもの, 酸溶出の最終段階で溶出された部分 にコロイド状シリカの高密度な集積が生じること ${ }^{8)}$ によ るものが考えられるが, その全体像は解明されていない.

ところで，この多孔質ガラスに添加成分の塩を含浸さ せた後, 乾燥, 焼成すると添加成分を含む無孔質高ケイ 酸ガラスが得られる. 多孔質ガラス中における添加成分 の濃度分布を制御し，無孔化後のガラスに適当な屈折率 分布を持たせるという方法で, 高ケイ酸ガラスからなる マイクロレンズ, 光学繊維等を作ることができる ${ }^{9) \sim 11)}$. このとき, コロイド状シリカの状態が添加成分の濃度分 布に影響するので，マイクロレンズなどの屈折率分布を
制御するためには，あらかじめ多孔質ガラス中のコロイ ド状シリカを除去することが必要とされる ${ }^{9)}$. 他方，コ ロイド状シリカを含む多孔質ガラスについて, 添加成分 の分布を測定すれば，コロイド状シリカの分布状態を調 ベることができると考えられる.

本研究では, このような考えに基づいて, 多孔質ガラ スのコロイド状シリカに起因する不均一性を検討した。 すなわち，棒状の多孔質ガラス試料に硝酸アルミニウム を含浸させたもの, それをアンモニアで処理して水酸化 アルミニウムを沈殿させたもの, 更にこの沈殿を硝酸で 溶解したもの, などを焼成して, 酸化アルミニウムを添 加した無孔質ガラス棒を作り，棒の断面のアルミニウム 濃度分布を調べて，コロイド状シリカに起因する多孔質 ガラスの不均一性との関連を検討した.

\section{2. 実験}

$\mathrm{SiO}_{2} 62.5$ wt $\%, \mathrm{~B}_{2} \mathrm{O}_{3} 27.3 \mathrm{wt} \%, \mathrm{Al}_{2} \mathrm{O}_{3} 3.0 \mathrm{wt} \%$, $\mathrm{Na}_{2} \mathrm{O} 7.2 \mathrm{wt} \%$ の組成のガラスを直径約 $4 \mathrm{~mm}$ の棒状に 成形し, $540^{\circ} \mathrm{C} て ゙ ~ 48 \mathrm{~h}$ 熱処理して分相させた. 次いで ガラス $1 \mathrm{~g}$ につき $500 \mathrm{~cm}^{3}$ の $500 \mathrm{~mol} / \mathrm{m}^{3}$ 硫酸を用い, $95^{\circ} \mathrm{C}$ で $50 \mathrm{~h}$ 溶出して多孔質ガラス棒とした後水洗, 乾 燥した。 
多孔質ガラスから酸化アルミニウム添加無孔質ガラス を作製する手順を図 1 及び表 1 に示す．試料 a は無含浸 の対照試料である. そのほかのシリーズの試料は, 表 1 に○印で示した処理を行い, 全試料とも焼成して無孔化 した.

b シリーズ及び e シリーズ試料について含浸液濃度の 効果を調べた．含浸液の濃度を表 2 に示す．そのほかの シリーズの試料は $16.2 \%$ の溶液を含浸させた. 含浸は 室温で $24 \mathrm{~h}$ 行った.

アンモニア処理は，含浸後表面の溶液をふき取った試 料を活栓付きデシケータ内で武薬特級のアンモニア水

(28\%) の蒸気にさらすことにより行った. f シリーズ の試料について, 表 3 に示すように時間を変えてアンモ ニア処理し，その効果を調べた. 他のシリーズの試料の

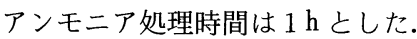

アンモニア処理試料の一部を $1000 \mathrm{~mol} / \mathrm{m}^{3}$ 硝酸で処 理した ( $\mathrm{g}$ シリーズ試料). 硝酸処理時間を表 4 に示す.

各試料は表 1 に示す処理が終わった後乾燥し,

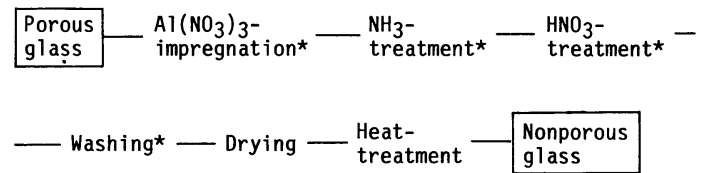

Fig. 1. Preparation process of nonporous high silica glass with $\mathrm{Al}_{2} \mathrm{O}_{3}$ addition. *Omitted in some specimens : see Table 1 .

Table 1. Treatment of porous galsses. $\mathrm{O}$ : treated, - : not treated.

\begin{tabular}{|c|c|c|c|c|}
\hline $\begin{array}{l}\text { Series of } \\
\text { specimens }\end{array}$ & $\begin{array}{l}\mathrm{Al}\left(\mathrm{NO}_{3}\right)_{3-} \\
\text { impregnation }\end{array}$ & $\begin{array}{l}\mathrm{NH}_{3-}^{-} \\
\text {treatment }\end{array}$ & $\begin{array}{l}\mathrm{HNO}_{3}^{-} \\
\text {treatment }\end{array}$ & Washing \\
\hline$a$ & - & - & - & - \\
\hline$\vec{b}$ & 0 & - & - & - \\
\hline c & 0 & - & - & 0 \\
\hline d & 0 & 0 & - & - \\
\hline$e, f$ & 0 & 0 & - & 0 \\
\hline$g$ & 0 & 0 & 0 & 0 \\
\hline
\end{tabular}

Table 2. Concentration of impregnated $\mathrm{Al}\left(\mathrm{NO}_{3}\right)_{3}$ solutions.

\begin{tabular}{cc}
\hline Specimen & Concentration / wtX \\
\hline b1, e1 & 9.5 \\
b2, e2 & 16.2 \\
b3, e3 & 25.2 \\
b4, e4 & 34.9 \\
\hline
\end{tabular}

Table 3. $\mathrm{NH}_{3}$-treatment time of f-series specimens.

\begin{tabular}{cc}
\hline Specimen & $\mathrm{NH}_{3}$-treatment time \\
\hline $\mathrm{f} 1$ & $10 \mathrm{~min}$ \\
$\mathrm{f} 2$ & $20 \mathrm{~min}$ \\
$\mathrm{f3}$ & $1 \mathrm{~h}$ \\
$\mathrm{f} 4$ & $5 \mathrm{~h}$ \\
$\mathrm{f5}$ & $24 \mathrm{~h}$ \\
\hline
\end{tabular}

Table 4. $\mathrm{HNO}_{3}$-treatment time of g-series specimens.

\begin{tabular}{cc}
\hline Specimen & $\mathrm{HNO}_{3}$-treatment time $/ \mathrm{h}$ \\
\hline $\mathbf{g} 1$ & 1 \\
$\mathbf{g} 2$ & 5 \\
$\mathbf{g} 3$ & 24 \\
\hline
\end{tabular}

$1070^{\circ} \mathrm{C}$ で $2 \mathrm{~h}$ 焼成して無孔化した. 含浸液濃度の高い $\mathrm{b} 4$ 及び e 4 試料の焼成温度は $1000^{\circ} \mathrm{C}$ とした. 得られ た無孔質ガラス棒を樹脂中に埋め込み，横断面を研磨し た. 研磨面の直径にそったアルミニウム濃度分布を $\mathrm{X}$ 線 マイクロアナライザー（島津製作所 EMX SM-7）を用 いて線分析した. 分析条件は加速電圧 $20 \mathrm{kV}$, 電流 $0.05 \mu \mathrm{A}$ ，試料の送り速度 $500 \mu \mathrm{m} / \mathrm{min}$ である.

\section{3. 結 果}

\section{1 濃度分布に対する各種処理の効果}

表 1 に示す処理を行った試料を乾燥，焼成する際に生 じるアルミニウムの移動はわずかで，焼成後の無孔質ガ ラスのアルミニウム濃度分布は未焼成の多孔質ガラスの ものと一致した.

図 2 に, 各シリーズ武料の断面のアルミニウム濃度分 布を示す. アルミニウムの濃度は $\mathrm{Al} K \alpha$ 線の信号強度で 表した (以下同じ). 未処理の $\mathrm{a}$ 試料では，表面付近の 濃度が高く，内部は平たんである．これに硝酸アルミニ ウムを含浸させた後乾燥，焼成した $\mathrm{b}$ 試料では，中心に 近い部分の濃度が著しく高くなるが，中心には幅の狭い 低濃度部分が生じている. 含浸試料を水洗すると, 大部 分のアルミニウムが洗い流されて, 未処理の $\mathrm{a}$ 試料に似 た分布に戻る. しかし, 未処理試料に比べると全体に濃 度は高い(試料 $\mathrm{c}$ ).

含浸試料をアンモニア処理し，細孔内のアルミニウム イオンを水酸化アルミニウムとして沈殿させると, 濃度

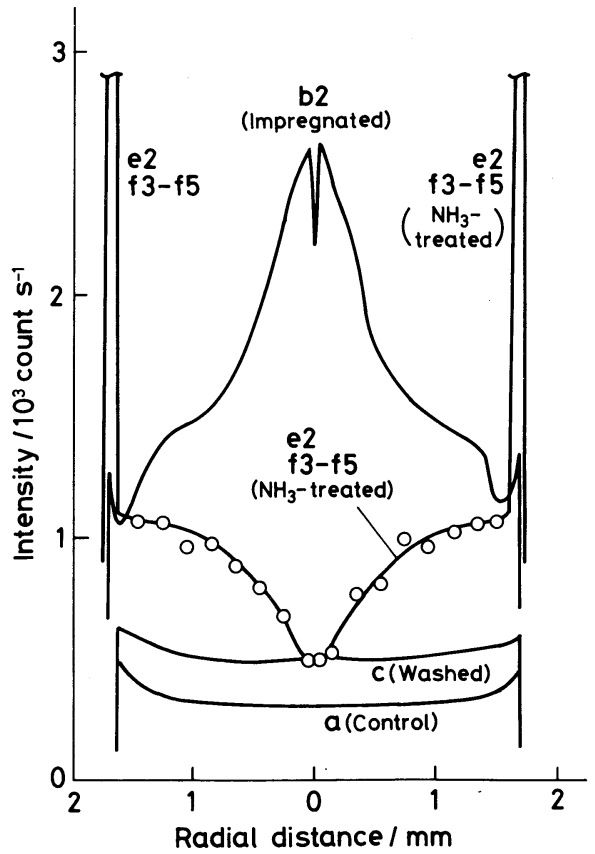

Fig. 2. Concentration profiles of Al. The notations on the curves indicate the series and the numbers of the specimens. The circles show the profile of specimen $d$. 
分布は大きく変化した. 図 2 には, アンモニア処理後水

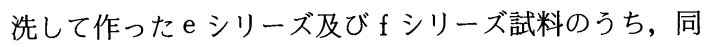
一の濃度分布曲線を示した試料 e 2, f 3 f 5 の分布を示 す.周辺から中心に向かってアルミニウム濃度が減少し, 中心の濃度は含浸後水洗した試料 $\mathrm{c}$ と等しくなってい る. また,これらのシリーズの試料では表面層が生成し, その部分のアルミニウム濃度が著しく高くなっている. アンモニア処理後水洗しないでそのまま乾燥させて作っ た d 試料も, e 2 及び $\mathrm{f} 3$ f 5 試料と同一の濃度分布を 示している.

\section{2 含浸液濃度の効果}

含浸液濃度が $\mathrm{b}$ シリーズ試料のアルミニウム濃度分布 に与える効果を図 3 に示す. 含浸液濃度が高くなると, 分布曲線の形はほぼ一定に保たれたまま全体の濃度が上

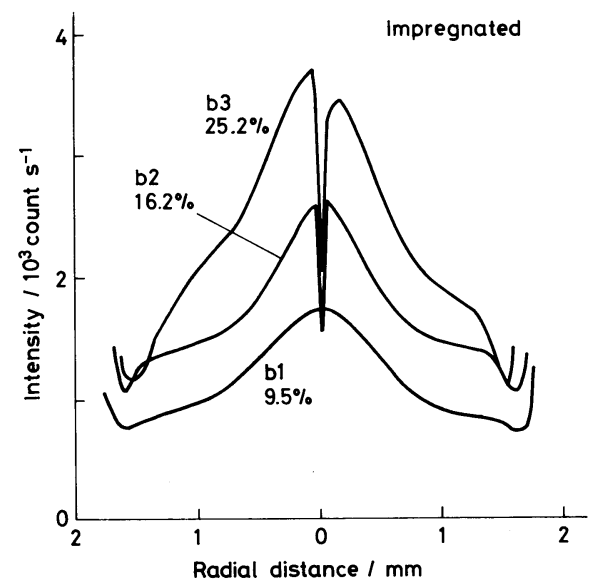

Fig. 3. Effect of concentration of impregnated solution on the $\mathrm{Al}$ concentration profile of $\mathrm{b}$-series specimens.

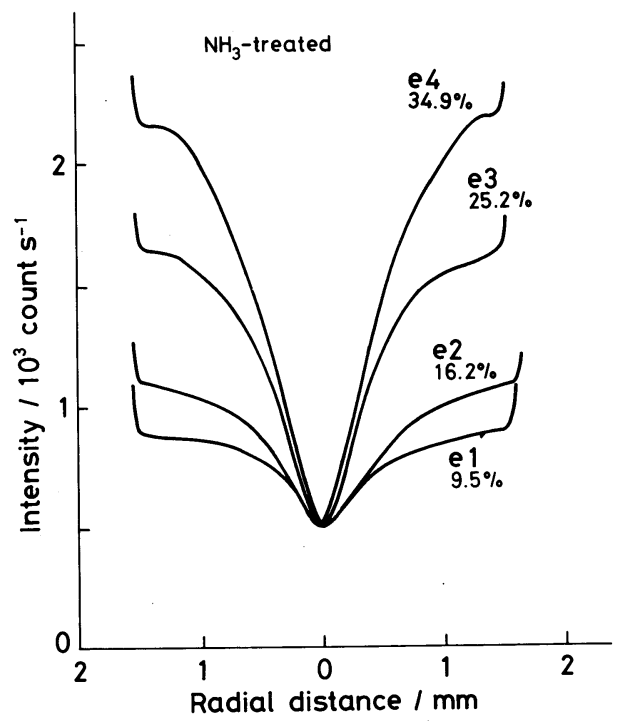

Fig. 4. Effect of concentration of impregnated solution on the Al concentration profile of e-series specimens.
昇する. b 1 試料では，中心部の低濃度部分が観察され なかったが，これは線分析した部分がわずかに中心を外 れていたためであろう. 図4 は, e シリーズ試料の濃度 分布に対する含浸液濃度の効果を示す.この場合も, 分 布曲線の形はほぼ一定で, 含浸液濃度の増加とともに全 体のアルミニウム濃度が高くなる. しかし，中心部のア ルミニウム濃度は含浸液濃度が変化しても変わらない.

$\mathrm{b}$ シリーズ試料について中心部の最高濃度, e シリー ズ試料について周辺に近い平たん部分の濃度を含浸液の 濃度に対してプロットした結果を図 5 に示す。図から， 両シリーズ試料ともアルミニウム濃度は含浸液濃度に対 して直線関係にあることが分かる. 含浸後水洗して作っ た $\mathrm{c}$ 試料の中心部のアルミニウム濃度を図の左端（縦軸 上）に示すが， $\mathrm{b}$ 試料の直線はこの点を通っている.

\section{3 アンモニア処理時間及び硝酸処理時間の効果}

含浸後時間を変えてアンモニア処理し, 水洗して作っ

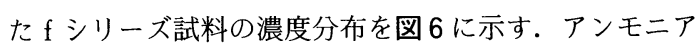
処理が $1 \mathrm{~h}$ 以上になると, 分布曲線は処理時間には影響 されず, f 3〜f 5 試料のように同一曲線になる.したがっ て, この曲線は飽和曲線と考えられる. アンモニア処理 時間の短い $\mathrm{f} 1, \mathrm{f} 2$ 試料では, 周辺部からアンモニアと の反応が進んでおり, 反応が終わった部分では分布は飽 和曲線と重なることが分かる. 中心部はアンモニアとの 反応が起こっていないため, 続く水洗によってアルミニ ウム濃度は $\mathrm{c}$ 試料の值まで低下する. 反応部分と未反応

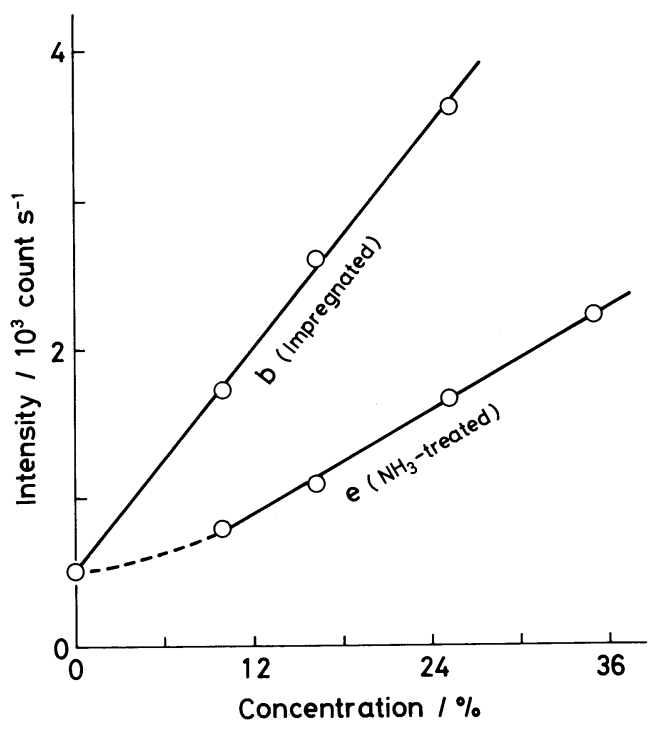

Fig.5. Relation between concentration of impregnated solution and $\mathrm{Al}$ concentration of sintered galss. Line $b$ shows the concentration of $b$-series specimens near the center where the concentration is highest and line e shows the concentration of e-series specimens at the surface region where the concentration profile is flat. 
部分との境界には, 幅の狭い高アルミニウム域が観察さ

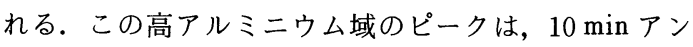
モニア処理した f 1 試料では, 反応部分, 未反応部分に 比べて著しく高いが，アンモニア処理時間が $20 \mathrm{~min} に$ なると著しく低下している (f 2). なお, 最外部の高ア ルミニウム層のピークの高さや形は一定していない. 図 6 に示したこの部分のピークは平均的なピークを模式的 に示している.

アンモニア処理の後硝酸で処理した試料のアルミニウ ムの分布を図 7 に示す. $1 \mathrm{~h}$ 処理した $\mathrm{g} 1$ 試料では, ア ンモニア処理の場合と同様反応部と未反応部との境界が 明りょうで, その部分にやはりアルミニウム濃度の高い 部分がある.しかし，硝酸処理時間が長くなるとこの境 界及び高アルミニウム域は消失し, アルミニウムが拡散 して溶出して行くことを推測させる分布曲線が得られ る. 反応はアンモニア処理の場合に比べて遅く, $1 \mathrm{~h}$ の 処理ではごく表面層だけしか反応していない（g 1 試

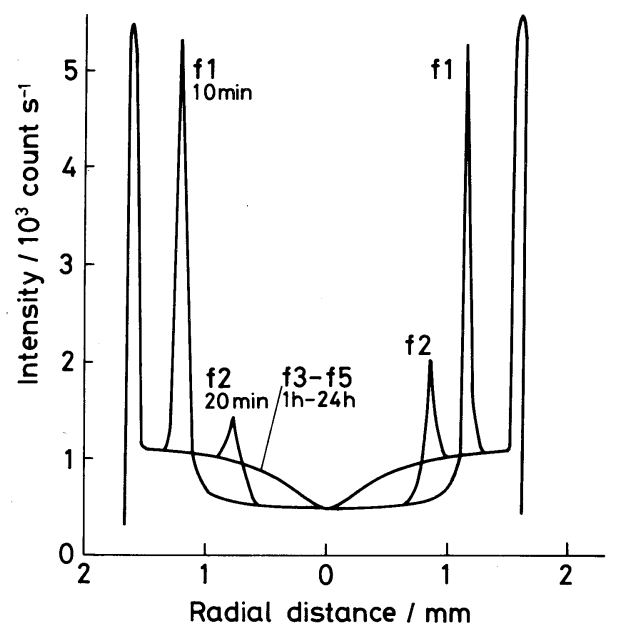

Fig. 6. Effect of $\mathrm{NH}_{3}$-treatment time of the $\mathrm{Al}\left(\mathrm{NO}_{3}\right)_{3}$ impregnated specimens on the concentration profile of Al.

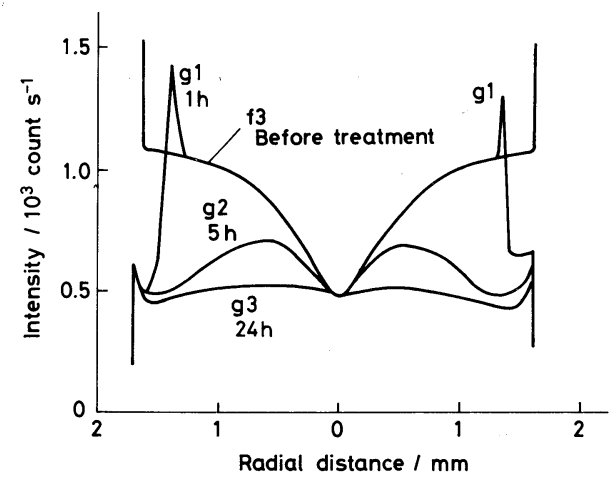

Fig. 7. Effect of $\mathrm{HNO}_{3}$-treatment time of the $\mathrm{Al}\left(\mathrm{NO}_{3}\right)_{3}$ impregnated and $\mathrm{NH}_{3}$-treated specimens on the concentration profiles of $\mathrm{Al}$.
料). $24 \mathrm{~h}$ 処理した $\mathrm{g} 3$ 試料でもアルミニウムは完全に は溶出しないことが分かる.

\section{4. 考 察}

4.1 コロイド状シリカに起因する多孔質ガラスの不 均一性

分相ガラスを酸溶出する際生成するコロイド状シリカ は, 多孔質ガラスの比表面積, 細孔分布などの特性に大 きい影響を与えるが，析出状態が一様でないため, 以下 に述べるような 3 種類の不均一性をもたらす.

第 1 は, コロイド状シリカの析出量の不均一性による ものである ${ }^{4), 6)}$. 表面付近では, 溶出時に可溶相中のシ リカが酸浴中に拡散しやすく，コロイドになる量が少な いのに対し，表面から遠い部分では逆にコロイドになる 量が多くなる.このため, 周辺から中心に向かってコロ イド状シリカの析出量が増加し, 細孔容積は減少すると 推論される.

第 2 は, コロイド状シリカの粒子が酸処理によって成 長し，それにつれて比表面積が減少する現象 ${ }^{7)}$ から生じ る不均一性である.試料表面に近い部分は初期に溶出し, その後溶出終了まで酸に触れているので, 末期に溶出さ れる中心部に比べると酸の作用を受ける時間が長くな る.したがって, 周辺部ほどコロイド粒子の成長が進み, このため表面積の不均一性が生じる.

第 3 は, 多孔質ガラスの中心におけるコロイド状シリ 力の高密度の集積に起因する不均一性である. 溶出の最 終段階でコロイド状シリカの著しく高密度の集積が生 じ，不均質部分を形成する ${ }^{8)}$.

\section{2 アルミニウムの濃度分布と不均一性}

図 8 は, 図 2 に示された各試料のアルミニウム濃度分 布曲線を模式化したものである. まず, 硝酸アルミニウ

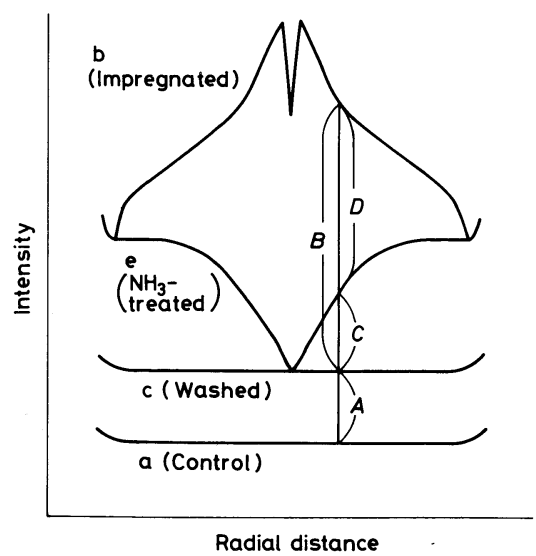

Fig. 8. Schematic illustration of concentration profiles of Al. $A$ : strongly adsorbed Al, $B$ : reversibly absorbed $\mathrm{Al}, C$ : precipitated $\mathrm{Al}$ after $\mathrm{NH}_{3}$-treatment, and $D:$ reversibly adsorbed $\mathrm{Al}$. 
ム含浸後, アンモニア処理と水洗を行って作った $\mathrm{e} シ$ リーズ試料のアルミニウム分布について考える. アンモ ニア処理により，細孔中の含浸液に含まれるアルミニウ ムが水酸化アルミニウムとして細孔中に沈殿するため, この試料のアルミニウム分布は細孔容積によって決定さ れ，細孔容積が大きい部分ほよ゙高くなるはずである．得 られたアルミニウム濃度の分布は, 予測どおり, コロイ ド状シリカの析出が少なくて細孔容積が大きいと考えら れる周辺部で高く, 細孔容積が小さい中心で小さくなっ ている.すなわち，第1の夕イプの不均一性による細孔 容積の分布が,アルミニウム濃度の分布に反映している.

硝酸アルミニウムを含浸した後乾燥, 焼成した b シ リーズの試料では, 中心部のアルミニウム濃度が高く, 周辺部の濃度が低くなる. このアルミニウム濃度は, 細 孔表面に吸着したアルミニウムと, 細孔内に溶液として 含まれるアルミニウムとの和である.したがって，b シ リーズ試料の濃度から, 細孔内に溶液として含まれてい たアルミニウムの量に対応する, $\mathrm{e}$ シリーズ試料のアル ミニウム濃度を差し引いた量（図 8 の $D$ で表されてい る量）が，表面に吸着していたアルミニウムの量に対応 する. ところで, 硝酸アルミニウムの代わりに硝酸ナト リウムを含浸させた場合にも, ナトリウムがシリーズ b の試料のアルミニウム濃度分布と同様の濃度分布を示 $す^{12)}$. その場合, 分相ガラスを溶出して多孔質ガラスを 作る際の酸処理時間が長くなるにつれて, 中心の濃度が 低下し，分布が平たんになる．そして，試料中心のナト リウム濃度の減少が, 4.1 節で述べた酸処理による表面 積の減少と一致していることから，ナトリウム吸着量は 表面積によって決定されると考えられる. アルミニウム の場合にも, 吸着量が表面積によって決定されると考え ると, 図 8 の $D$ の大きさが試料内の表面積の分布を表 していることになる，Dに相当する濃度の分布を図 9 に示す。ここに見られる, 中心が高く, 周辺が低い表面 積分布は, 第 1 のタプの不均一性, すなわち, 中心部 ほどコロイド状シリカの析出量が多いこと, 及び第 2 の タイプの不均一性, すなわち，周辺部のコロイド状シリ カが粒子成長を起こして比表面積が小さくなっているこ とが重なり合って生じたものと考えられる.

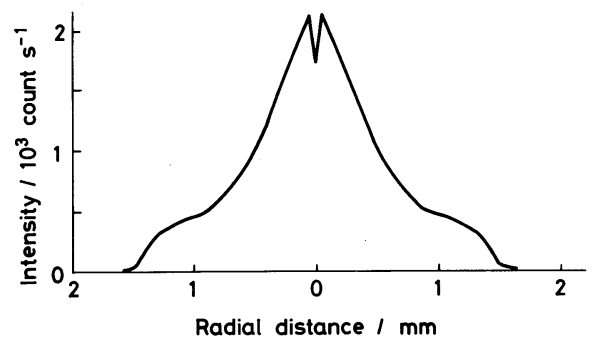

Fig. 9. Concentration profile of reversibly adsorbed Al. $\mathrm{b}$ シリーズ試料の中心に見られる, 幅の狭い低アルミ ニウム部分は, 次のように第 3 のタイプの不均一性, す なわちコロイド状シリカの高密度集積で説明できる. コ ロイド状シリカの高密度の集積が半透膜としての性格を 持ち ${ }^{13)}$ １5), 含浸液中のアルミニウムイオンの浸透を阻 止するので, その結果中心部のアルミニウム濃度が低く なるものと考えられる.

\section{3 アルミニウムの濃度分布に影響するそのほかの 因子}

図 2 から明らかになように，含浸処理だけを行ったb シリーズ試料に比べて, 更にアンモニア処理を行った $\mathrm{e}$ シリーズ試料の方がアルミニウム濃度が低い.このこと は，過剩量に相当する部分（図 8 の $D$ ） がアンモニア 処理に伴って試料外に出て行くことを示している. アン モニア処理後水洗せずに焼成した $\mathrm{d}$ 試料の濃度分布が $\mathrm{e}$ シリーズのものと同一である（図 2 ）ことから，過剩の アルミニウムは水洗によって除かれるのではなく，アン モニア処理時又はその後の乾燥の際に試料外に移動する と思われる. e 試料表面のアルミニウム濃度の高い層は, 試料内から移動して来たアルミニウムが集積して生じた ものであろう. 図 6 , 図 7 に示されているように, アン モニア処理，あるいはそれに続く硝酸処理の際，反応が 終わった領域と未反応の領域との間にアルミニウム濃度 の高い部分が生じるが，これもアルミニウムの移動に関 連する現象であろう。しかし，このようなアルミニウム の移動については不明な点が多く, その解明には更に検 討が必要であると思われる.

アンモニア処理に伴うアルミニウムの移動と, 図 6 に 見られる高アルミニウム部分の形成は, 処理後の試料の アルミニウム濃度分布に影響する可能性がある.しかし， アンモニア処理後細孔内に沈殿した水酸化アルミニウム の量 (図 8 の C) は, 図 5 の直線 $\mathrm{e}$ から明らかなように, 含浸液濃度に対し直線関係にあり, 比例関係からのずれ も小さい. また, 図 6 から分かるように, アンモニア処 理時間が長くなるにつれて高アルミニウム部分の濃度は 急速に低下している. これらのことから，アンモニア処 理時のアルミニウムの移動が最終的な濃度分布に与える 影響はあまり大きくない.

上記のほかに，アルミニウム濃度分布について；次の ような点が指摘できる.

未含浸試料 $\mathrm{a}$ の濃度分布で, 周辺部のアルミニウムが 中心より高濃度になっているのは, 出発ガラスの表面部 のアルミニウム濃度が高いため ${ }^{16)}$ と考えられる.

図 8 の $A$, すなわち $\mathrm{a}$ 試料と $\mathrm{c}$ 試料の濃度差は, 水 洗によって除去できない, 強く吸着したアルミニウムの 存在を示している.

含浸後アンモニア処理した e シリーズの試料の濃度分 布曲線は, 濃度が最小になる中心点で $\mathrm{c}$ 試料の曲線と重 
なっている（図 2). 図 4 から分かるように，この点の 濃度は含浸液の濃度を変えても変化しない. これらのこ とから, e シリーズ武料においても $\mathrm{c}$ 試料と同量の強く 吸着したアルミニウムが存在すること, これら両試料の 差, すなわち図 8 の $C$ で示した量が細孔内に沈殿した アルミニウムの量を表すこと, 試料中心では細孔容積が ごく小さく, 水酸化アルミニウムの沈殿はほとんど生じ ないことが分かる.

\section{5. 総 括}

多孔質ガラス棒に硝酸アルミニウム水溶液を含浸さ せ，アンモニアで処理し，焼成してアルミニウム添加無 孔質ガラスとした後, 断面の直径上のアルミニウム濃度 分布を求めたところ, 含浸後アンモニア処理せずに作っ た試料では，中心の濃度が高く，周辺に向かって低下す る濃度分布が生じ，含浸後アンモニア処理すると，中心 部が低濃度で, 周辺部に向かって増加する分布が得られ ることが分かった。

得られた濃度分布と，多孔質ガラス中のコロイド状シ リカに起因する不均一性との関連を検討した。アンモニ ア処理して作った試料のアルミニウムの分布は, 多孔質 ガラス内の細孔容積の分布と関連づけられること，すな わち, 中心部でコロイド状シリカの析出量が多く, 細孔 容積が小さい状態と対応することが分かった，また，含 浸だけ行った試料の濃度から，アンモニア处理した試料 の濃度を減じたものは, 多孔質ガラス内の表面積の分布 に対比し,この表面積の分布は, コロイド状シリカの析 出量の分布及びコロイド状シリカの比表面積の酸処理に
よる変化から生じたものと考えることができた，含浸だ け行った試料の中心に, 幅の狭い低濃度部分が観察され るが, これは多孔質ガラスを作る際の酸溶出の最終段階 で生成する, コロイド状シリカの高密度の集積によるも のと解釈した。

\section{文献}

1）江口清久ほか, “ガラスの事典”, 作花済夫編, 朝倉書店 (1985) p. 214-15.

2) S.P. Zhdanov, "The Structure of Glass", Consultants Bureau (1958) p. 125-34.

3) T.H. Elmer, M.E. Nordberg, G. B. Carrier and E. J. Korda, J. Am. Ceram. Soc., 53, 171-75 (1970).

4) T. Takamori, J. Am. Ceram. Soc., 61, 434-38 (1978).

5) H. Tanaka, T. Yazawa, K. Eguchi, H. Nagasawa, N. Matsuda and T. Einishi, J. Non-Cryst. Solids, 65, 301-09 (1984).

6）田中博史, 矢沢哲夫, 江口清久, 山黒隆夫, 窯協, 92, 492-97 (1984)

7）田中博史, 窯協, 85, 587-90 (1977).

8) H. Tanaka, T. Yazawa and K. Eguchi, Yogyo-KyokaiShi, 91, 384-86 (1983).

9) P. B. Macedo and T. A. Litovitz, U. S. Pat. 3938974 (1976).

10) J.H. Simmons, R. K. Mohr, D. C. Tran, P. B. Macedo and T. A. Litovitz, Appl. Opt., 18, 2732-33 (1979).

11) Y. Asahara, H. Sakai, S. Shingaki, S. Ohmi, S. Nakayama, K. Nakagawa and T. Izumitani, Appl. Opt., 24, 4312-15 (1985).

12）田中博史, 大工試季報, 28, 107-12 (1977).

13) E. V. Ballou, M. I. Leban and T. Wydeven, Nature, 229, 123-24 (1971).

14) T. H. Elmer, Am. Ceram. Soc. Bull., 57, 1051-53, 1060 (1978).

15）矢沢哲夫，田中博史，江口清久，山黒隆夫，日化，1985, 866-70.

16) M. Tomozawa and T. Takamori, J. Am. Ceram. Soc., 62, 370-73 (1979). 